\title{
Short-term effects of habitat fragmentation on the abundance and species richness of beetles in experimental alfalfa microlandscapes
}

\author{
Efectos a corto plazo de la fragmentación del hábitat sobre la abundancia y riqueza de \\ especies de coleópteros en micropaisajes experimentales de alfalfa
}

\author{
AUDREY A. GREZ ${ }^{*}$, TANIA ZAVIEZO² \& SUSANA REYES ${ }^{1}$ \\ ${ }^{1}$ Facultad de Ciencias Veterinarias y Pecuarias, Universidad de Chile, Casilla 2 Correo 15, La Granja, Santiago, Chile \\ ${ }^{2}$ Facultad de Agronomía e Ingeniería Forestal, Pontificia Universidad Católica de Chile, Casilla 306 - 22, Santiago, Chile \\ *Corresponding author: agrez@uchile.cl
}

\begin{abstract}
Habitat loss and fragmentation are considered as the main causes of biodiversity depression. Habitat loss implies a reduction of suitable habitat for organisms, and habitat fragmentation is a change in the spatial configuration of the landscape, with the remaining fragments resulting more or less isolated. Recent theory indicates that the effects of habitat loss are more important than those of habitat fragmentation, however there are few experimental studies evaluating both processes separately. To test the effects of habitat fragmentation per se on the abundance, species richness and diversity of epigeal coleopterans, 15 (30 x 30 $\mathrm{m})$ alfalfa microlandscapes, distributed in three blocks, were created. On twelve of them, $84 \%$ of the habitat was removed, leaving in each landscape four or 16 fragments separated by 2 or $6 \mathrm{~m}$ of bare ground. From December 2002 to April 2003, before and after fragmentation, coleopterans were sampled using pitfall traps. In total, 8,074 coleopterans of 75 species belonging to 16 families were captured. Neither habitat fragmentation nor habitat loss affected the total abundance of coleopterans, with the exception of Anthicidae that was more abundant in the microlandscapes composed by four fragments separated by $2 \mathrm{~m}$. This family was also more abundant in the matrix of fragmented microlandscapes, while most other beetle families were more abundant in the fragments, significantly Carabidae and Lathridiidae. Species richness (per trap and per landscape) was higher in microlandscapes with 16 fragments separated by $6 \mathrm{~m}$. Contrary to what is described frequently in the literature, habitat fragmentation did not negatively affect the abundance or the species richness of epigeal coleopterans. Rather, smaller and more isolated alfalfa fragments seem to provide habitat to support greater biodiversity. These results agree with more recent findings where habitat fragmentation per se seems not to have deleterious effects on the fauna, instead, it could favor the biota, at least at short time scales.
\end{abstract}

Key words: habitat fragmentation, habitat loss, microlandscapes, diversity of epigeal beetles.

\section{RESUMEN}

La pérdida y fragmentación del hábitat han sido consideradas como las principales causas de la disminución de biodiversidad. La pérdida de hábitat es una disminución del hábitat utilizable por los organismos y la fragmentación es un cambio en la configuración espacial del paisaje, donde los fragmentos remanentes quedan relativamente aislados entre sí. Trabajos teóricos recientes indican que los efectos de la pérdida de hábitat son más importantes que los de la fragmentación, sin embargo existen pocos estudios experimentales que evalúen por separado ambos procesos. Para estudiar los efectos de la fragmentación per se sobre la abundancia y riqueza de especies de coleópteros epigeos, se crearon 15 micropaisajes de alfalfa de 30 x $30 \mathrm{~m}$ distribuidos en tres bloques. Doce de ellos se fragmentaron removiendo el $84 \%$ del hábitat, dejando cuatro ó 16 fragmentos separados por 2 ó $6 \mathrm{~m}$. Entre diciembre del 2002 y abril del 2003, antes y después de la fragmentación, se muestrearon los coleópteros mediante trampas Barber. Se capturó un total de 8.074 coleópteros de 75 especies pertenecientes a 16 familias. El tipo de paisaje no afectó la abundancia de coleópteros, solo Anthicidae fue más abundante en los paisajes de 4 fragmentos separados por $2 \mathrm{~m}$ y fue más abundante en la matriz. El resto de las familias fue más abundante en los fragmentos, significativamente Carabidae y Lathridiidae. La riqueza de especies por trampa y por paisaje fue mayor en los paisajes con 16 fragmentos separados por $6 \mathrm{~m}$, concentrándose en los fragmentos. Contrario a lo descrito en la mayor parte de la literatura, la fragmentación no afectó negativamente la abundancia y riqueza de especies de coleópteros epigeos asociados a alfalfa. Más bien, fragmentos de alfalfa más pequeños y aislados ofrecieron un refugio de hábitat para la biodiversidad de coleópteros epigeos. Estos resultados concuerdan con los postulados más 
recientes que indican que la fragmentación per se puede no tener efectos sobre la biota, o incluso puede favorecerla, al menos en el corto plazo.

Palabras clave: fragmentación del hábitat, pérdida de hábitat, micropaisajes, diversidad de coleópteros epigeos.

\section{INTRODUCTION}

Habitat fragmentation is a process in which one continuous habitat is transformed into a larger number of smaller patches, of smaller total area, isolated from each other by a matrix, which is usually compositional or structurally different from the original habitat (Wilcove et al. 1986). This process implies habitat loss, but also a change in habitat configuration (i.e., habitat fragmentation per se, Fahrig 2003), that implies different number of fragments or relative isolation among them. Classical theories in community and population ecology, such as the theory of island biogeography (MacArthur \& Wilson 1967) and metapopulation dynamics (Levins 1969), predict that smaller and more isolated fragments should support an impoverished fauna, compared to larger and closer fragments. Many empirical data have supported these predictions, suggesting that habitat fragmentation negatively affects the abundance and species richness of organisms (Wilcove et al. 1986, Quinn \& Harrison 1988, Baur \& Erhardt 1995), including insects (Klein 1989, Didham 1997, Gilbert et al. 1998). But, since most researchers have not separated the effects of habitat loss and habitat configuration (McGarigal \& Cushman 2000, but see Caley et al. 2001), these negative effects attributed to habitat fragmentation may be representing only the negative effect of habitat loss. Fahrig (2003) pointed out in a recent review that while habitat loss has large, consistent negative effects on biodiversity, habitat fragmentation per se has a much weaker effect, and may be negative but also often positive. These positive effects have been recorded in voles (Collins \& Barret 1997), crabs (Caley et al. 2001) and insects (Collinge \& Forman 1998, Tscharntke et al. 2002). On the one hand, habitat fragmentation may increase population density through a "crowding effect", where surviving individuals move from the removed habitat to the remaining fragments (Collinge \& Forman 1998, Debinski \& Holt 2000). Nevertheless, this may be a short-term effect (Debinski \& Holt 2000). On the other hand, habitat fragmentation may increase species richness, both at the fragment (i.e., local, $\alpha$ species diversity) as well as at the landscape (i.e., regional, $\gamma$ species diversity) level, not only because of the crowding effect, but also because a series of small- or medium sized fragments distributed in a larger area and relatively far apart from each other, may capture a much greater habitat heterogeneity than only one large fragment (Tscharntke et al. 2002).

One way of separating the effects of habitat loss and fragmentation is through manipulative experiments that control for one of these factors (McGarigal \& Cushman 2002). Even though there is much to be gained in the development of fragmentation theory from carefully designed experiments, they are scarce in the literature (Hunter 2002, McGarigal \& Cushman 2002, Holt \& Debinski 2003), but increasing in the last years (e.g., Collinge \& Forman 1998, Gilbert et al. 1998, Caley et al. 2001, With et al. 2002, Hoyle \& Gilbert 2004). Many of these manipulative experiments are run at a small temporal and spatial scale, relevant to small-bodied and short living organisms, such as insects and other arthropods, and even though they might not be directly extrapolated to larger scale systems, they may provide insights for hypotheses to be tested later at larger scales.

In this paper, we studied the short-term effects of habitat loss and fragmentation per se (i.e., number and isolation of fragments) on the abundance and species richness of epigeal beetles in experimentally created alfalfa (Medicago sativa L) microlandscapes. As fragmentation is a landscape process, and its effects may depend on how organisms use the resulting landscape mosaic, we not only studied the abundance and species richness of beetles in the remaining alfalfa fragments but also in the surrounding matrix, a usually forgotten aspect in fragmentation studies (Tschnartke \& Brandl 2004, but see Cronin 2003).

\section{MATERIAL AND METHODS}

This study was carried out at Antumapu Experimental Research Station, University of

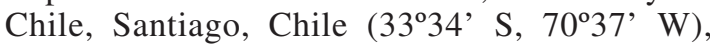
between September 2002 and April 2003. The first week of September, we plowed a 5 ha 
field, and sowed alfalfa (Pioneer 5683), creating $15 \quad 30 \quad x \quad 30 \quad \mathrm{~m}$ experimental microlandscapes (here after landscapes) linearly distributed in three blocks, each one containing five landscapes separated by $20 \mathrm{~m}$. Blocks were $50 \mathrm{~m}$ apart. The second week of December, 12 out of 15 landscapes were fragmented with a plough, leaving four or 16 square fragments separated by 2 or $6 \mathrm{~m}$, and surrounded by a bare ground matrix, which was kept without vegetation through additional plowing and herbicides as needed. Three landscapes were kept undisturbed (Control). Therefore, we created five kind of landscapes: $4 \mathrm{fr}-2 \mathrm{~m}$ (4 fragments separated by $2 \mathrm{~m}$ ), 4 fr- $6 \mathrm{~m}$ (4 fragments separated by $6 \mathrm{~m}), 16 \mathrm{fr}-2 \mathrm{~m}$ (16 fragments separated by $2 \mathrm{~m}), 16 \mathrm{fr}-6 \mathrm{~m}$ (16 fragments separated by $6 \mathrm{~m}$ ) and a control (unfragmented) landscape, $0 \%$ habitat loss), each one replicated three times and randomly distributed in each block (see Fig. 1). In all fragmented landscapes we removed a constant amount of alfalfa $(84 \%)$. This amount of habitat loss is over the threshold level where the effects of habitat fragmentation per se are theorically predicted to have significant effects (Andrén 1994, Fahrig 1998, Flather \& Bevers 2002). The distance between fragments ( 2 or 6 m) used in this experiment are relevant at least for ladybeetles (Coleoptera: Coccinellidae), because they have a higher interchange between fragments when they are closer $(2 \mathrm{~m})$ than when they are far apart $(6 \mathrm{~m})$ (Grez et al. in press). This design allow us to test the jointed effects of habitat loss and fragmentation when comparing the control with fragmented landscapes, and the effect of habitat fragmentation per se (i.e., number of fragments and distance among fragments) when comparing only fragmented landscapes.

Epigeal beetles, those that concentrate their activity at ground level, were sampled with pitfall traps every two weeks in seven occasions: one previous to fragmentation and six after fragmentation. Pitfall traps is the usual method for sampling epigeal insects. This method is not the most appropriate for direct estimation of absolute true density, but it is useful to compare population size and community structure in space and time (Dent \& Walton 1997, Duelli et al. 1999, Perner \& Schueler 2004). The traps consisted in a plastic, transparent container, $6 \mathrm{~cm}$ diameter and $8 \mathrm{~cm}$ depth $(250 \mathrm{~mL})$, half-filled with a solution of water, formalin $(10 \%)$, and detergent. We placed a total of 240 traps, 16 in each

Block
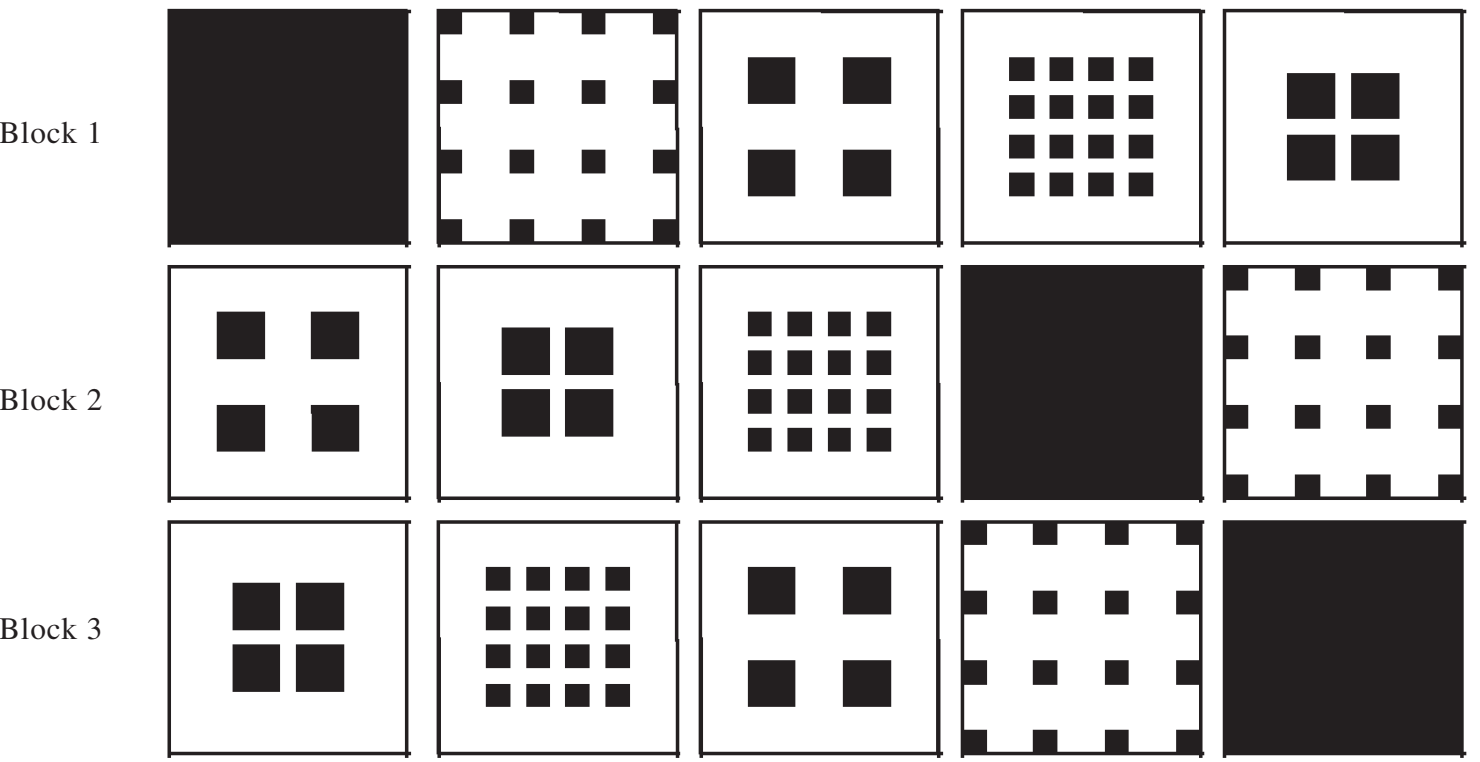

Block 3
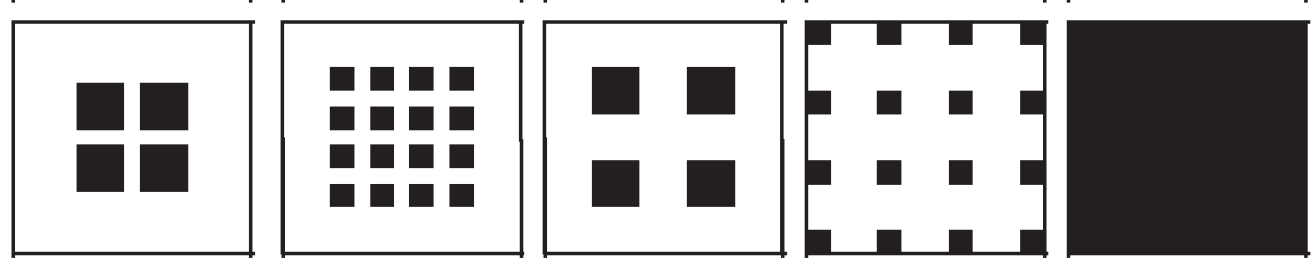

Fig. 1: Experimental layout showing the distribution of the five kinds of microlandscapes in each block. The matrix is represented in white and fragments and control in black. Blocks were separated by at least $50 \mathrm{~m}$ and microlandscapes within blocks by at least $20 \mathrm{~m}$.

Diseño experimental mostrando la distribución espacial de los cinco tipos de micropaisajes en cada bloque. La matriz está representada en blanco y los fragmentos y el micropaisaje control en negro. Los bloques quedaron separados por al menos $50 \mathrm{~m}$ y los paisajes dentro de los bloques por $20 \mathrm{~m}$. 
landscape. In order to assay the effect of the kind of habitat (i.e., alfalfa fragments or bare ground matrix) on the abundance or species richness of beetles, half of the traps were placed in the fragments and half in the matrix of the fragmented landscapes. In the control, the 16 traps were distributed throughout the landscape. The traps were kept open during four nights and days, and then brought to the laboratory where insects were identified following taxonomic keys or by comparison with reference collections.

We calculated the number of beetles (abundance) and the number of different species (species richness) per trap in each landscape, considering all traps and also separating among traps from alfalfa fragments and from the matrix. We also calculated the number of species per landscape because different fragments of the same landscape may harbour the same number of species, but they might differ in their composition.

Abundance and species richness data were analyzed through repeated measures ANOVAs, with block, type of landscape, and family as the independent variables and time as the repeated measure. Also, with the abundance and species richness data from the fragmented landscapes (i.e., excluding the control) we run the same kind of ANOVA, but with fragmentation (4 or
16 fragments), distance ( 2 or $6 \mathrm{~m}$ ) and kind of habitat (fragments or matrix) as the independent variables. Tukey tests were run for multiple comparisons. Since data satisfied normality and homogeneity of variance assumptions of the ANOVA, we did not transform them. To avoid pseudoreplication (Hurlbert 1984), the data used in the ANOVAs were the mean abundance or mean species richness of each landscape (average from all traps). STATISTICA (Statsoft, 2000) were used for all the statistical analyses.

\section{RESULTS}

In total we captured 8,074 beetles from 16 families and 75 species (Appendix 1). Total abundance of beetles was not affected by landscape's kind $\left(\mathrm{F}_{4,10}=1.36, \mathrm{P}=0.31\right.$; Fig. $2)$. Anthicidae was the most abundant family throughout the experiment, accounting for over $50 \%$ of total captured beetles. Because of this, we repeated the analysis without this family, but the abundance of beetles was still similar among landscapes $\left(\mathrm{F}_{4,10}=0.71, \mathrm{P}=0.59\right)$. At the family level, only Anthicidae was more abundant in the $4 \mathrm{f}_{\mathrm{r}}-2 \mathrm{~m}$ landscape than in the $4 \mathrm{f}_{\mathrm{r}}-6 \mathrm{~m}$ and the Control (Landscape * Family effect, $\left.\mathrm{F}_{64,170}=1.43, \mathrm{P}<0.05\right)$.

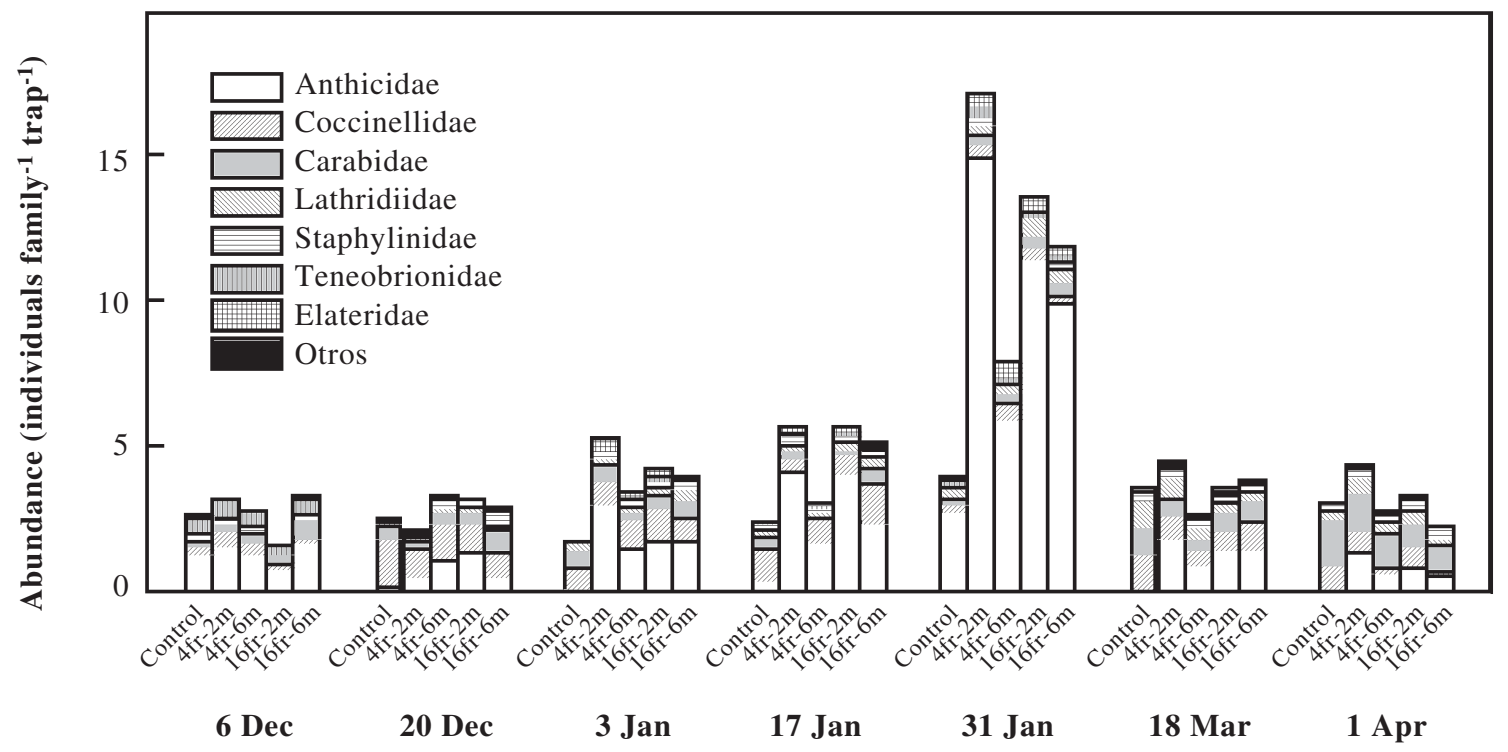

Fig. 2: Total and per family beetle abundance trap ${ }^{-1}$ in different alfalfa microlandscapes, from December 2002 to April 2003.

Abundancia total y por familia de coleópteros epigeos trampa ${ }^{-1}$ en diferentes micropaisajes de alfalfa, entre diciembre 2002 y abril 2003 
When considering only the fragmented landscapes, there was no significant effect of fragmentation ( 4 or 16 fragments, $F_{1,16}=0.04$, $\mathrm{P}=0.83)$, distance between fragments (2 or 6 $\mathrm{m}, \mathrm{F}_{1,16}=1.88, \mathrm{P}=0.18$ ) or kind of habitat (fragments or matrix, $\mathrm{F}_{1,16}=2.9, \mathrm{P}=0.1$ ) on the total abundance of beetles per trap. At the family level, Anthicidae was more abundant in the landscapes with fragments separated by $2 \mathrm{~m}$ $\left(F_{15,256}=2.21, P=0.01\right)$, and in the matrix than in the fragments $\left(\mathrm{F}_{15,256}=12.01, \mathrm{P}<\right.$ 0.001 ), while Carabidae and Lathridiidae were more abundant in the fragments, when Anthicidae was removed from the analysis $\left(\mathrm{F}_{14}\right.$, $240=22.25, \mathrm{P}<0.01$; Fig. 3).

Regarding beetle species richness per trap, it varied from one to three species. When comparing the five different kind of landscapes, species richness per trap was significantly higher in the $16 \mathrm{f}_{\mathrm{r}}-6 \mathrm{~m}$ landscapes and lower in the Control, particularly on 17 January $\left(\mathrm{F}_{4,10}=3.38, \mathrm{P}=0.05\right.$; Fig. 4$)$. When looking at beetle species richness per landscape, it varied from 9 to 20 species, and similarly to species richness per trap, in most of the sampling dates, it was significantly higher in the $16 \mathrm{f}_{\mathrm{r}}-6 \mathrm{~m}$ landscape than in the control $\left(\mathrm{F}_{4}\right.$, $10=7.86, \mathrm{P}<0.01$; Fig. 5).

When considering only the fragmented landscapes, beetle species richness per trap was
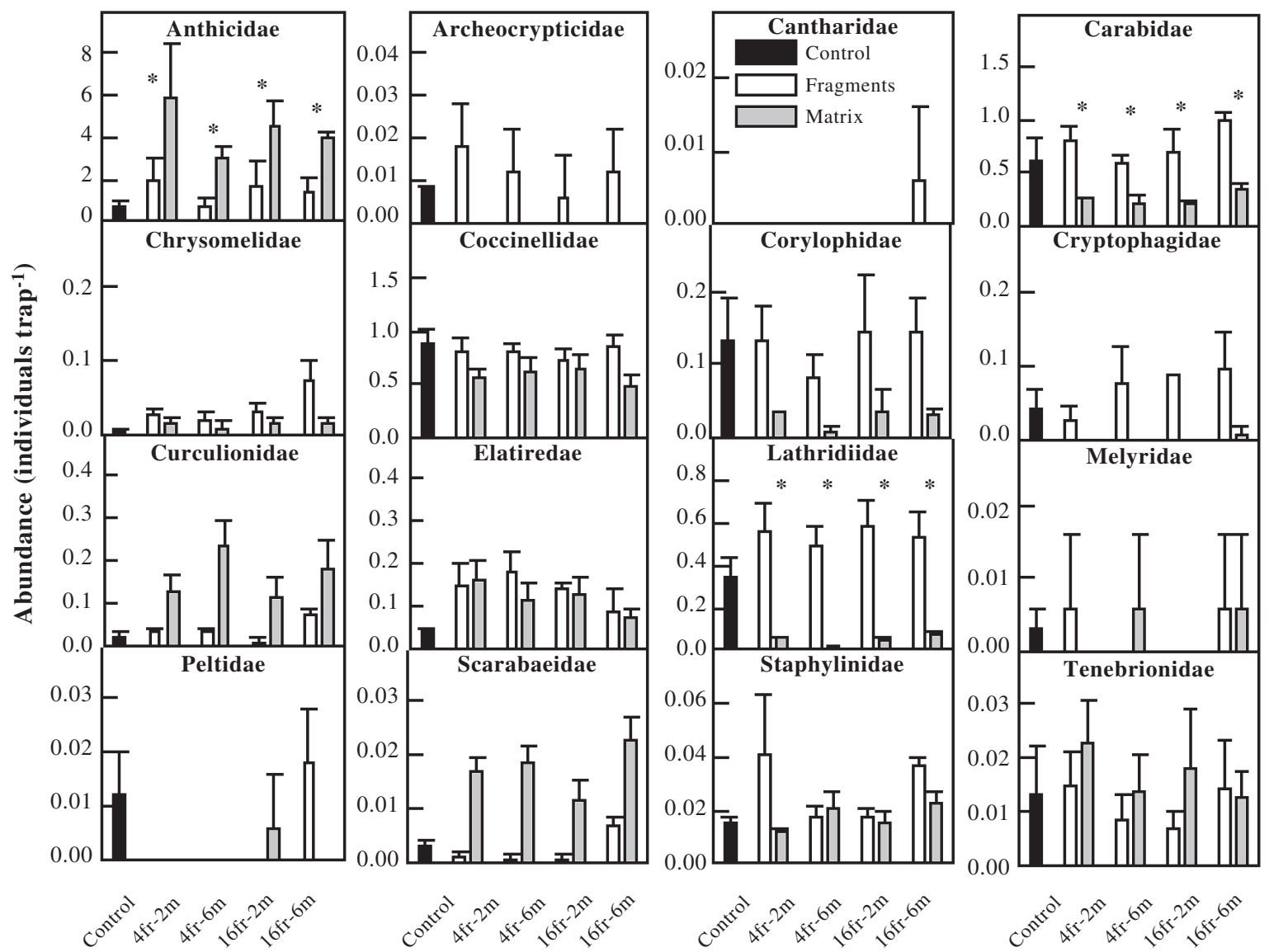

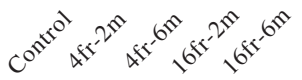

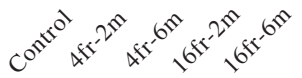

\section{Treatment}

Fig. 3: Abundance of different families of beetle $\operatorname{trap}^{-1}$ (mean \pm 1 SE) in the fragments and matrix of the different alfalfa microlandscapes, from December 2002 to April 2003. Control is shown as a reference but was not considered for the statistical analysis. Legends of the bars indicated in Cantharidae; * indicate significant different abundance between habitats (Tukey, $\mathrm{P}<0.05$ ).

Abundancia de diferentes familias de coleópteros trampa-1 (media $\pm 1 \mathrm{EE}$ ) en los fragmentos y matriz de diferentes micropaisajes de alfalfa, entre diciembre 2002 y abril 2003. El Control se muestra como referencia, pero no fue incluido en el análisis estadístico; * indican abundancias significativamente diferentes entre hábitats (Tukey, $\mathrm{P}<0,05)$. 


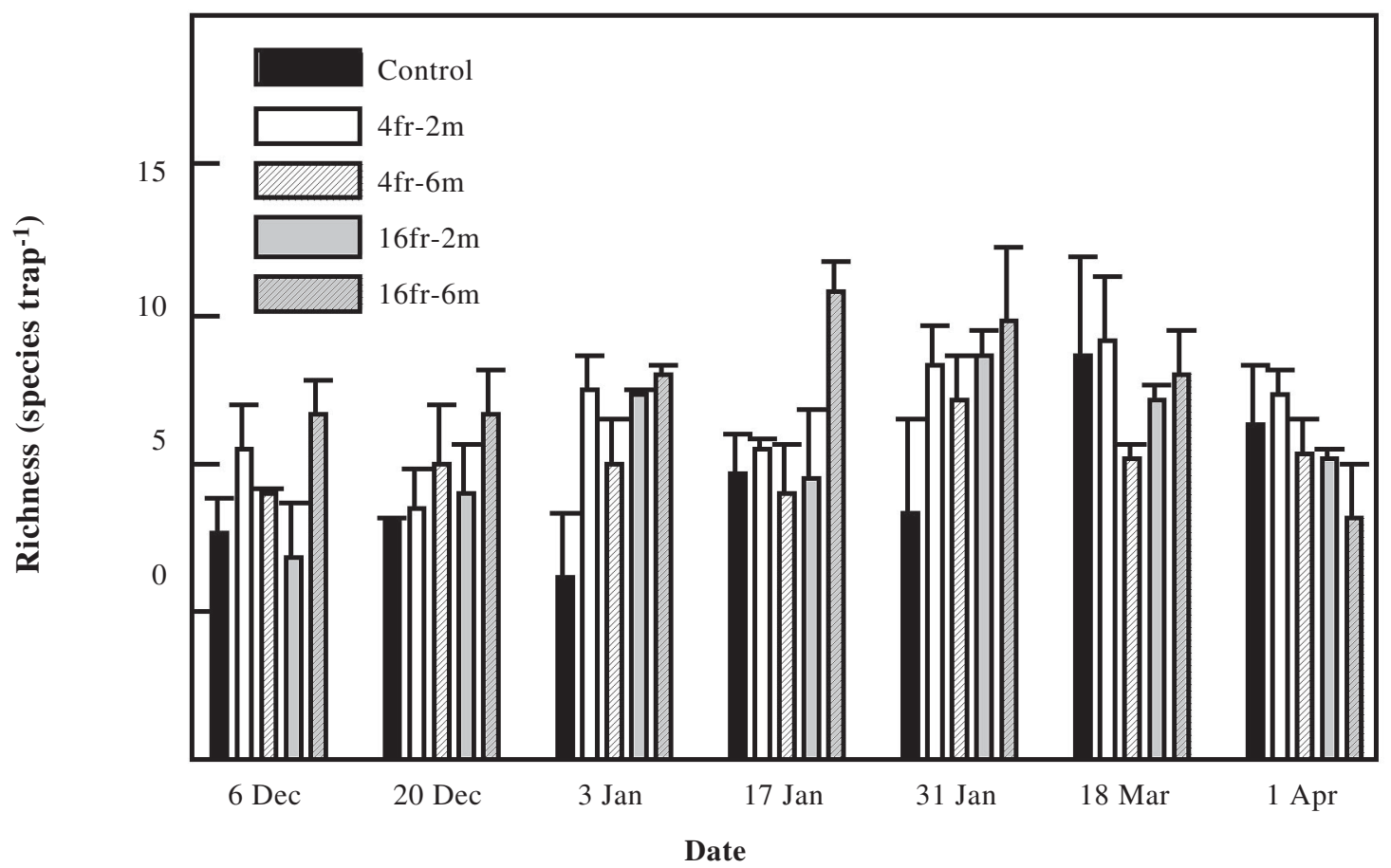

Fig. 4: Species richness of beetles trap ${ }^{-1}$ (mean $\pm 1 \mathrm{SE}$ ) in different alfalfa microlandscapes, from December 2002 to April 2003.

Riqueza de especies de coleópteros trampa ${ }^{-1}$ (media $\pm 1 \mathrm{EE}$ ) en diferentes micropaisajes de alfalfa, entre diciembre 2002 y abril 2003.

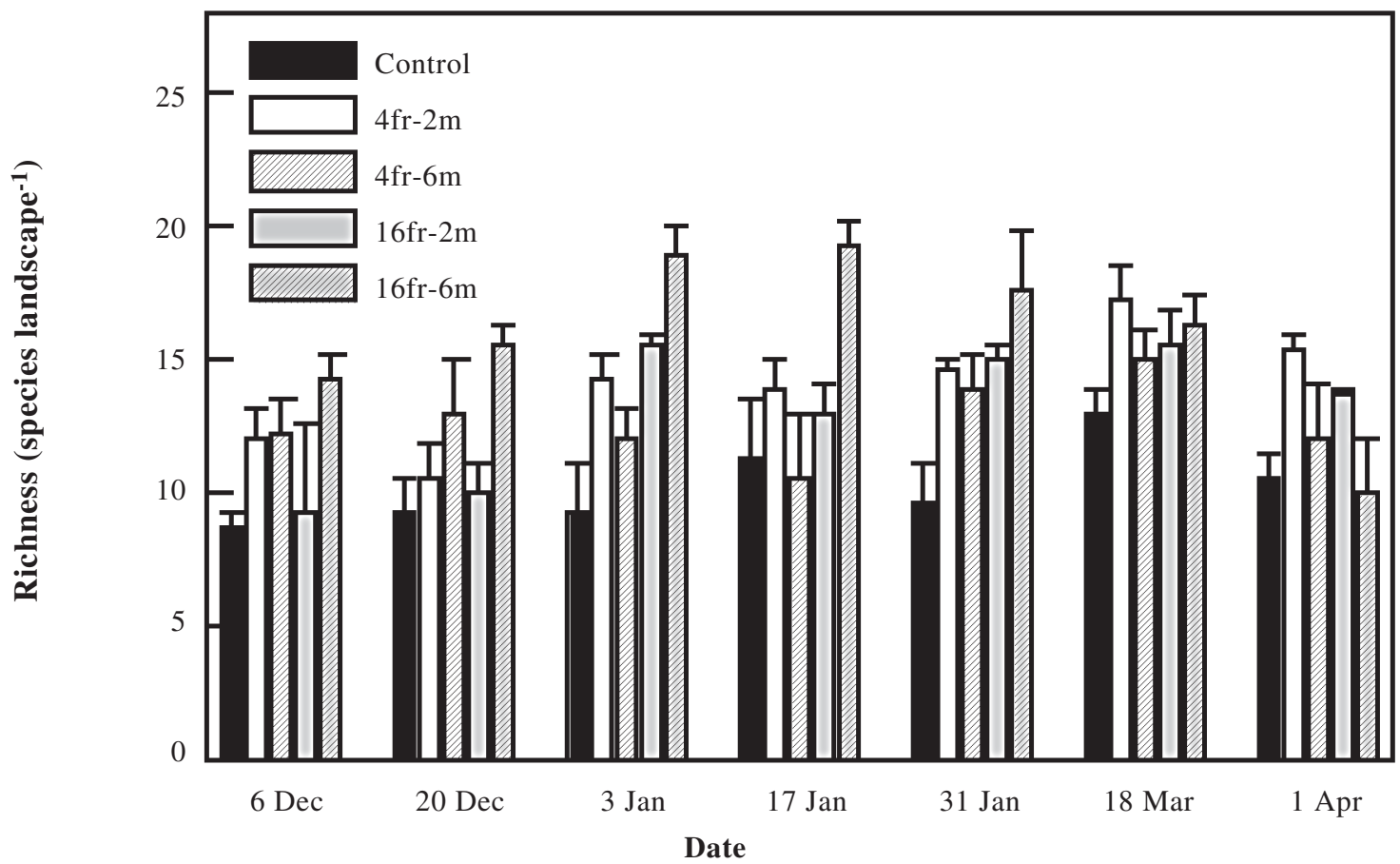

Fig. 5: Species richness of beetles landscape ${ }^{-1}$ (mean $\pm 1 \mathrm{SE}$ ) in different alfalfa microlandscapes, from December 2002 to April 2003.

Riqueza de especies de coleópteros epigeos paisaje ${ }^{-1}$ (media $\left.\pm 1 \mathrm{EE}\right)$ en diferentes micropaisajes de alfalfa, entre diciembre 2002 y abril 2003 
not affected by fragmentation or distance between fragments $\left(\mathrm{F}_{1,16}=2.41, \mathrm{P}=0.13\right.$ and $\mathrm{F}_{1,16}=0.002, \mathrm{P}=0.96$, respectively), but it was affected by the kind of habitat $\left(\mathrm{F}_{1,16}=21.43\right.$, $\mathrm{P}$ $<0.001$ ), being higher in the fragments than in the matrix. There was a significant interaction between fragmentation and distance $\left(\mathrm{F}_{1,16}=\right.$ 8.27, $\mathrm{P}<0.01)$, with the highest species richness per trap achieved in the landscapes with 16 fragments when they were separated by $6 \mathrm{~m}$, corroborating the previous analysis where the five landscapes were compared. Similar results were obtained with the beetle species richness per landscape (Fragmentation effect, $\mathrm{F}_{1,16}=0.02, \mathrm{P}=0.87$; Distance effect, $\mathrm{F}_{1,16}=$ $0.34, \mathrm{P}=0.56$; Habitat effect, $\mathrm{F}_{1,16}=14.0, \mathrm{P}<$ 0.001 ; Fragmentation $*$ Distance effect, $\mathrm{F}_{1,16}=$ $5.62, \mathrm{P}<0.05)$.

\section{DISCUSSION}

In general, beetle abundance -in total or per family- was not significantly affected by the kind of landscape, although there was only a minor trend of a higher abundance in the fragmented versus unfragmented (control) microlandscape, which would suggest that habitat loss, when combined with fragmentation, might have no effect or only a minor positive effect on beetle abundance, contrary to what was expected (Fig. 2). Since in this experiment we did not include a microlandscape that only vary in habitat loss, we don't know if the negative effect of habitat loss was compensated by a positive effect of fragmentation.

Except for Anthicidae, which was more abundant in the matrix, most beetle families tended to be more abundant in the fragments than in the matrix (significantly Carabidae and Lathridiidae). The highest abundance of beetles in fragments was an expected result, because the matrix probably have scarce or nil biotic resources and harsh abiotic conditions for them. Carabidae are mainly predators of many herbivorous insects such as aphids, which are abundant in alfalfa. Also some species of this family are seed consumers, and it has been demonstrated that these food resources determine the distribution and abundance of carabids in several crops when comparing with surrounding bare ground (Honek \& Jarosik 2000). Lathridiidae, on the other hand, are saprophagous, so their resources should be also concentrated in the fragments. What was an unexpected result was the high abundance of Anthicidae in the matrix, also a saprophagous family. Nevertheless, in a previous study we have shown that this family is more abundant in cut than in uncut alfalfa (Zaviezo et al. 2004). Furthermore, it was the only family affected by the kind of landscape and distance between fragments, being more abundant in the $4 \mathrm{f}_{\mathrm{r}}-2 \mathrm{~m}$ landscape. Compared with the other fragmented landscapes, this one had the largest extent of a continuous matrix surrounding the fragments (Fig. 1), a habitat that may provide some biotic or abiotic conditions that they tolerate better than other beetle species. Also, since pitfall traps measure not only the density of organisms but also their activity in different substrates (Southwood 1980, McEven 1997, Perner \& Schueler 2004), perhaps the larger number of Anthicidae captured in the matrix than in the fragments may reflect only their higher activity in the bare ground compared with the alfalfa habitat, since the former is a simpler homogeneous substrate, where insects probably displace faster. This seems not to have occurred with the other beetle families, since they were lower or equally captured in matrix than in fragments (Fig. 3).

The species richness was affected by the kind of landscape, with the smaller number of species, per trap and per landscape, in the control and the highest in the fragments of the $16 \mathrm{f}_{\mathrm{r}}-6 \mathrm{~m}$ landscapes (Figs. 4 and 5). This is opposite to what is predicted by the island biogeography theory (MacArthur \& Wilson 1967) and to what has been documented in most empirical studies, where insects species richness decay in smaller and more isolated fragments (e.g., Klein 1989, Aizen \& Feinsinger 1994, Didham 1997). But, this increase in beetle species richness with increase in fragmentation and isolation is similar to what has been observed with endangered polifagous butterflies in agricultural landscapes of Germany (Tschanrtke et al. 2002), with insects assemblages associated with grasslands in North America (Collinge \& Forman 1998), and with ground dwelling beetles in temperate forest in Chile (Grez in press). These results, along with ours, suggest that smaller and more isolated fragments may support more species of insects than larger patches ( $\alpha$ diversity), and also that more fragmented landscapes may harbor an enriched fauna of insects compared to an equivalent continuous area ( $\gamma$ diversity). It seems more likely that distant fragments would have more independent colonization events by different species than a group of fragments that are close together. Moreover, isolation of fragments may make the redistribution of these species across the 
landscape more difficult (Gilbert et al. 1998). Thus, in highly fragmented landscapes the species composition would vary more from fragment to fragment than in less isolated or continuous landscapes, with the consequent higher species richness at the landscape level (Tscharntke et al. 2002).

Although beetles usually have short lifecycles, with one or more generations in a couple of months (e.g., coccinellids, personal observations), our results may describe only short-term effects of habitat fragmentation on beetle abundance and species richness (i.e., four months after fragmentation), which might be appropriate for many agricultural ecosystems, they do not necessarily constitute "equilibrium" conditions for insects in more "stable" landscapes (Collinge \& Forman 1998). Nevertheless, there are studies where the increased abundance of organisms, due to habitat fragmentation, has been found several generations after habitat removal (i.e., several months to a year or more for small vertebrates, and for several weeks for insects) (Lovejoy et al. 1986, McGarigal \& McComb 1995, Collinge \& Forman 1998). Immediately after fragmentation, mechanisms like immigration and emigration are very important in determining population abundance or species richness in fragmented landscapes. At longer temporal scales, reproduction and mortality may turn to be more relevant, and may reverse the initial effects of habitat fragmentation. In fact, the initial crowding effects of fragmentation may not be benign when considering longer temporal scales, precisely because density-dependent factors such as competition for limited resources may be exacerbated under crowded conditions, and have a negative influence on individual survival and reproduction (Collinge \& Forman 1998). Thus, mechanisms like these should be evaluated in future studies in order to comprehend their relative importance in shaping beetle response to habitat fragmentation, both shortly after fragmentation and at a longer time scale.

In summary, based on a manipulative experiment that controlled for habitat loss, we have demonstrated that habitat fragmentation per se might not negatively affect insect abundance in microlandscapes, and may increases species richness, both at a local and at a landscape level, at least at short time scales. These results, along with those from many recent studies that show that habitat fragmentation per se is not necessarily negative for some organisms, may be useful for practical purposes such us biodiversity conservation and pest management.

\section{ACKNOWLEDGEMENTS}

Thanks to Denise Donoso, Marta Ríos, Astrid Pérez, Bernardino Camousseigt, Sandra Díaz, Galaxia Cortés, Gonzalo Cid, and Patricio Vásquez for their field assistance. This study was supported by FONDECYT 1011041.

\section{LITERATURE CITED}

AIZEN MA \& P FEINSINGER (1994) Habitat fragmentation, native insects pollinators, and feral honeybees in Argentine "Chaco Serrano". Ecological Applications 4: 378-392.

ANDRÉN H (1994) Effects of habitat fragmentation on birds and mammals in landscapes with different proportions of suitable habitat: a review. Oikos 71: 355-366.

BAUR B \& A ERHARDT (1995) Habitat fragmentation and habitat alterations: principal threats to most animals and plant species. Gaia 4: 221-226.

CALEY MJ, KA BUCKLEY \& GP JONES (2001) Separating ecological effects of habitat fragmentation, degradation, and loss on coral comensals. Ecology 82: 3435-3448.

COLLINGE SK \& RTT FORMAN (1998) A conceptual model of land conversion processes: predictions and evidence from a microlandscape experiment with grassland insects. Oikos 82: 66-84.

COLLINS RJ \& GW BARRET (1997) Effects of habitat fragmentation on meadow vole (Microtus pennsylvanicus) population dynamics in experiment landscape patches. Landscape Ecology 12: 63-76.

CRONIN JT (2003) Matrix heterogeneity and host-parasitoid interactions in space. Ecology 84: 1506-1516.

DEBINSKI DM \& RD HOLT (2000) A survey and overview of habitat fragmentation experiments. Conservation Biology 14: 342-355.

DENT D \& MP WALTON (1997) Methods in ecological and agricultural Entomology. CAB International, Wallingford, United Kingdom. 387 pp.

DIDHAM RK (1997) An overview of invertebrate responses to forest fragmentation. In: Watt $\mathrm{AD}, \mathrm{NE}$ Stork \& MD Hunter (eds) Forests and insects: 303320. Chapman and Hall. London, United Kingdom.

DUELLI P, MK OBRIST \& DR SCHMATZ (1999) Biodiversity evaluation in agricultural landscapes: above-ground insects. Agriculture, Ecosystems and Environments 74: 33-64.

FAHRIG L (1998) When does fragmentation of breeding habitat affect population survival? Ecological Modelling 105: 273-292.

FAHRIG L (2003) Effects of habitat fragmentation on biodiversity. Annual Review of Ecology and Systematics 34: 487-515.

FLATHER CH \& M BEVERS (2002) Patchy reactiondiffusion and population abundance: the relative importance of habitat amount and arrangement. American Naturalist 159: 40-56.

GILBERT F, A GONZALEZ \& I EVANS-FREKE (1998) Corridors maintain species richness in the fragmented landscapes of a microecosystem. 
Proceedings of the Royal Society of London B 265: 577-582.

GREZ AA (in press) El valor de los fragmentos pequeños de bosque Maulino en la conservación de la fauna de coleópteros epigeos. In: Smith-Ramírez C, J Armesto \& C Valdovinos (eds) Biodiversidad y Ecología de los bosques de la cordillera de la Costa de Chile. Editorial Universitaria, Santiago, Chile.

GREZ AA, T ZAVIEZO \& M RÍOS (in press) Ladybird (Coleoptera: Coccinellidae) dispersal in fragmented alfalfa landscapes. European Journal of Entomology.

HOLT RD \& DM DEBINSKI (2003) Reflections on landscape experiments and ecological theory: tools for the study of habitat fragmentation. In: Bradshaw GA \& PA Marquet (eds) How landscapes change. Ecological Studies 162: 201-223.

HONEK A \& V AJROSIK (2000) The role of crop density, seed and aphid presence in diversification of field communities of Carabidae (Coleoptera). European Journal of Entomology 97: 517-525.

HOYLE M \& F GILBERT (2004) Species richness of moss landscapes unaffected by short-term fragmentation. Oikos 105: 359-367.

HUNTER MD (2002) Landscape structure, habitat fragmentation, and the ecology of insects. Agricultural and Forest Entomology 4: 159-166.

HURLBERT SH (1984) Pseudoreplication and the design of ecological field experiments. Ecological Monographs 54: 187-211.

KLEIN BC (1989) Effects of forest fragmentation on dung and carrion beetle communities in central Amazonia. Ecology 70: 1715-1725.

LEVINS R (1969) Some demographic and genetic consequences of environmental heterogeneity for biological control. Bulletin of the Entomological Society of America 15: 237-240.

LOVEJOY TE, RO BIRREGAARD, AB RYLANDS, JR MALCOLM, CE QUINTELA, LH HARPER, KS BROWN, GVN POWELL, HOR SCHUBART \& M HAYS 1986. Edge an other effects of isolation in Amazonian forest fragments. In: Soulé ME (ed) Conservation biology: the science of scarcity and diversity: 257-285. Sinauer, Sunderland, Massachusetts, USA.

MACARTHUR RH \& EO WILSON (1967) The theory of island biogeography. Princeton University Press, Princeton, New Jersey, USA. 192 pp.
MCEVEN P (1997) Sampling, handling and rearing insects. In: Dent DR \& MP Walton (eds), Methods in ecological and agricultural entomology: 5-26. CAB International, Wallingford, United Kingdom.

MCGARIGAL K \& WC MCCOMB (1995) Relationships between landscape structure and breeding birds in the Oregon Coast Range. Ecological Monographs 65: 235-260.

MCGARIGAL K \& SA CUSHMAN (2002) Comparative evaluation of experimental approaches to the study of habitat fragmentation effects. Ecological Applications 12: 335-345.

PERNER J \& S SCHUELER (2004) Estimating the density of ground-dwelling arthropods with pitfall traps using a nested-cross array. Journal of Animal Ecology 73: 469-477.

QUINN JF \& SP HARRISON (1988) Effects of habitat fragmentation and isolation on species richness: evidence from biogeographic patterns. Oecologia 75: $132-140$.

SOUTHWOOD TRE (1980) Ecological methods. Second edition. Chapman and Hall. Cambridge, United Kingdom. 524 pp.

STATSOFT (2000) Statistica. Vol 1: General conventions and statistic Statsoft, Tulsa, Oklahoma, USA. 1877 pp.

TSCHARNTKE T, I STEFFAN-DEWENTER, A KRUESS \& C THIES (2002) Contribution of small habitat fragments to conservation of insect communities on grassland - cropland landscapes. Ecological Application 12: 354-363.

TSCHNARTKE T \& R BRANDL (2004) Plant-insect interactions in fragmented landscapes. Annual Review of Entomology 49: 405-430.

WILCOVE DS, CH MCLELLAN \& AP DOBSON (1986) Habitat fragmentation in the temperate zone. In: Soulé ME (ed) Conservation Biology: 237-256. Sinauer, Sunderland, Massachusetts, USA.

WITH KA, DM PAVUK, JL WORCHUCK, RK OATES \& JL FISHER (2002) Threshold effects of landscape structure on biological control in agroecosystems. Ecological Applications 12: 52-65.

ZAVIEZO T, AA GREZ \& D DONOSO (2004) Dinámica temporal de coleópteros asociados a alfalfa. Ciencia e Investigación Agraria (Chile) 31: 29-38. 


\section{APPENDIX 1}

Mean abundance $( \pm 1$ SE, $n=240)$, of families and species of epigeic beetles captured in pitfall traps from December 2002 to April 2003. Different letters indicate significant difference among sampling dates (Tukey $\mathrm{P}<0.05$ )

Abundancia promedio ( $\pm 1 \mathrm{EE}, \mathrm{n}=240$ ) de familias y especies de coleópteros epigeos capturados en trampas Barber entre diciembre del 2002 y abril del 2003. Letras diferentes indican diferencias significativas entre las fechas $($ Tukey $\mathrm{P}<0,05)$

Beetle abundance per trap (mean $\pm 1 \mathrm{SE})$

Family/ species

6 Dec 200220 Dec 20023 Jan 2003 17 Jan 2003 31 Jan 200318 Mar 20031 Apr 2003

Anthicidae

Total

Gen. sp. 1

$1.3 \pm 0.1 \quad 1 \pm 0.1 \quad 2 \pm 0.4$

$1.3 \pm 0.1$

$1 \pm 0.1$

$2 \pm 0.4$

$2.5 \pm 1.1$

$2.5 \pm 1.1$

$9 \pm 4.4$

$1.1 \pm 0.1$

$9 \pm 4.4$

$1.1 \pm 0.1$

$1 \pm 0.1$

Archeocrypticidae

Total

Archeocryptus topali

0

0

$0 \quad 0.004 \pm 0$

$0.01 \pm 0$

$0.01 \pm 0$

$0.01 \pm 0$

Cantharidae

Total

Polemius denticornis

$0 \quad 0.004 \pm 0$

$0.004 \pm 0$

$0.01 \pm 0 \quad 0.03 \pm 0.01$

(2)

$0.004 \pm 0$

0

0

0
0
0
0
0

Carabidae

Total

Agonum ambigus

Anisotarsus cupripennis

Calosoma vagans

Crossonychus sp.

Feroniomorpha aerea

Metius chilensis

Pterostichus sp.

Pterostichus unistriatus

Stenolophina sp.

Gen. sp. 1

Gen. sp. 2

$0.33 \pm 0.1$
$0.1 \pm 0.02$
$0.01 \pm 0$

$0.5 \pm 0.11$

$0.1 \pm 0.04$

$0.01 \pm 0.01$

$0.1 \pm 0.02$

$0.05 \pm 0.02$

$0.2 \pm 0.1$

$0.03 \pm 0.01$

$0.5 \pm 0.1$

$0.1 \pm 0.04$

$0.004 \pm 0$

$0.2 \pm 0.04$

$0.1 \pm 0.01$

$0.004 \pm 0$

$0.02 \pm 0$

$0.04 \pm 0.03$

$0.1 \pm 0.03$

$0.004 \pm 0 \quad 0.001 \pm 0$

$\begin{array}{rr}0 & 0.004 \pm 0 \\ 0.1+0.01 & 0.1 \pm 0.02\end{array}$

$\begin{array}{rr}0.1 \pm 0.01 & 0.1 \pm 0.02 \\ 0.02 \pm 0.01 & 0.02 \pm 0.02\end{array}$

$0.01 \pm 0.01$

$0.01 \pm 0.01$

$\begin{array}{ll}0 & 0.03 \pm 0.03\end{array}$

$0.004 \pm 0$

$0.004 \pm 0$

$0.004 \pm 0$

0

$0.3 \pm 0.1$

$0.1 \pm 0.03$

$0.01 \pm 0$

$0.1 \pm 0.1$

$0.05 \pm 0.02$

0

$0.004 \pm 0$

$0.1 \pm 0.02$

$0.03 \pm 0.01$

$0.01 \pm 0$

$0.01 \pm 0.01$

$0.02 \pm 0$

$0.004 \pm 0$

$0.01 \pm 0.01$

Jansonius aeneus

Lithraeus scutellaris

Pseudopachymerina spinipes

Coccinellidae

Total

Cicloneda sanguinea

Eriopis connexa

Hippodamia convergens

Hippodamia variegata

Hyperaspis sphaeridiodes

Scymnus loewii

Scymnus bicolor

Scymnus sp.

Gen. sp. 1

Corylophidae

Total

Gen. sp. 1

$$
\begin{array}{rrr}
0.3 \pm 0.11 & 1.1 \pm 0.21 & 1 \pm 0.24 \\
0 & 0 & 0.004 \pm 0 \\
0.33 \pm 0.1 & 1 \pm 0.2 & 1 \pm 0.3 \\
0.01 \pm 0 & 0.02 \pm 0 & 0.04 \pm 0.01 \\
0.1 \pm 0.04 & 0.1 \pm 0.03 & 0.1 \pm 0.02 \\
0 & 0.01 \pm 0.01 & 0.02 \pm 0.01 \\
0.004 \pm 0 & 0.004 \pm 0 & 0.01 \pm 0 \\
0 & 0 & 0 \\
0 & 0 & 0.008 \pm 0 \\
0 & 0.004 \pm 0 & 0.004 \pm 0
\end{array}
$$

$\begin{array}{rr}0.1 \pm 0.02 & 0.01 \pm 0.01 \\ 0 & 0 \\ 0.1 \pm 0.02 & 0.01 \pm 0.01 \\ 0 & 0\end{array}$

$$
\begin{array}{rr}
0.03 \pm 0 & 0.03 \pm 0.01 \\
0 & 0 \\
0.03 \pm 0 & 0.01 \pm 0.01 \\
0.004 \pm 0 & 0
\end{array}
$$

$$
\begin{array}{r}
0.4 \pm 0.1 \\
0.1 \pm 0.02 \\
0 \\
0.01 \pm 0.01 \\
0.07 \pm 0.05 \\
0.004 \pm 0 \\
0 \\
0.1 \pm 0.04 \\
0.1 \pm 0.01 \\
0 \\
0
\end{array}
$$

$1 \pm 0.1$ 0

)

$1 \pm 0.1$

$1+0.11$

$1 \pm 0.11$

$1 \pm 0.05$

$0.2 \pm 0.03$

$0.1 \pm 0.02$

$0.02 \pm 0.0$

$0.004 \pm 0$

0

$$
0.4 \pm 0.1
$$

$0.2 \pm 0.04$

$0.02 \pm 0.02$

$0.1 \pm 0.04$

$0.04 \pm 0.01$

$0.01 \pm 0.01$

$0.02 \pm 0.02$

$0.02 \pm 0.02$

$1 \pm 0.15$
0
$0.2 \pm 0.04$
$0.1 \pm 0.1$
$1 \pm 0.1$
$.04 \pm 0.02$
$0.02 \pm 0$
$0.01 \pm 0.01$
0
0

$0.2 \pm 0.1$
$0.2 \pm 0.1$

$0.1 \pm 0.02$

$0.2 \pm 0.1$

$0.2 \pm 0.1$

$0.1 \pm 0.02$

$\begin{array}{lll}0.01 \pm 0.01 & 0.03 \pm 0.01 & 0.1 \pm 0.01\end{array}$

$0.1 \pm 0.02$

$0.1 \pm 0.03$

$0.02 \pm 0$

$0.1 \pm 0.04$

$0.02 \pm 0.01$

Total

Cryptophagus sp. 1 $\begin{array}{lll}0 & 0.004 \pm 0 & 0.1 \pm 0.033\end{array}$

$0 \quad 0.004 \pm 0$

$0.1 \pm 0.03$
$0.01 \pm 0.01$

$0.1 \pm 0.04$

$0.02 \pm 0.01$

Cryptophagus sp. 2

0

0

$0 \quad 0.1 \pm 0.03$

$0.004 \pm 0$

$0.004 \pm 0$

$0.004 \pm 0$
$1.14 \pm 0.03$

$0.03 \pm 0.01$

$0.004 \pm 0$

$0.02 \pm 0.01$

$0.1 \pm 0.03$

$0.3 \pm 0.1$

$0.004 \pm 0$

$\pm 0.02$

$0.4 \pm 0.1$

$\pm 0$

0 
Beetle abundance per trap (mean $\pm 1 \mathrm{SE})$

Family/species

6 Dec 200220 Dec 2002 3 Jan 2003 17 Jan 2003 31 Jan 2003 18 Mar 20031 Apr 2003

Curculionidae

Total

Atrichonotus taeniatulus

Hypurus bertrandi

Listroderes sp.

Listronotus pionaerensis

Naupactus xanthographus

Neopachytychius squamosus

Sitona discoideus

Otiorhynchus rugosus

.

$0.1 \pm 0.04 \quad 0.02 \pm 0.02 \quad 0.03 \pm 0.02$

$0.1 \pm 0.04 \quad 0 \quad 0.01 \pm 0.01$

$0.01 \pm 0$

$\begin{array}{rrr}0 & 0 & 0.004 \pm 0 \\ 0 & 0.004 \pm 0 & 0 \\ 0.004 \pm 0 & 0.004 \pm 0 & 0.01 \pm 0.01\end{array}$

$$
\begin{array}{rr}
0.004 \pm 0 & 0 \\
0 & 0.01 \pm 0 \\
0 & 0.004 \pm 0 \\
0.004 \pm 0 & 0 \\
0.004 \pm 0 & 0.01 \pm 0.01 \\
0 & 0
\end{array}
$$

Elateridae
Total

Conoderus rufangulus

Grammophorus minor

Lathridiidae

Total

Aridius sp.

Corticaria serrata

Melanophtalma seminigra

Melyridae

Total

Amecocerus sp. 2

Arthrobrachus sp.

Astylus trifasciatus

Peltidae

Total

Decamerus haemorrhoidalis

$\begin{array}{rrr}0.1 \pm 0.02 & 0.03 \pm 0 & 0.2 \pm 0.02 \\ 0.1 \pm 0.02 & 0.02 \pm 0.02 & 0.2 \pm 0.02 \\ 0.01 \pm 0 & 0.01 \pm 0.01 & 0.01 \pm 0.01\end{array}$

$0.03 \pm 0.02$

$\begin{array}{rr}0.1 \pm 0.02 & 0.3 \pm 0.04 \\ 0 & 0.01 \pm 0.01 \\ 0.1 \pm 0 & 0.1 \pm 0.02\end{array}$

\begin{tabular}{ll}
$0.1 \pm 0$ & $0.1 \pm 0.02$ \\
\hline & 0.01
\end{tabular}

$0.03 \pm 0.02$

$0.04 \pm 0.0$

$\begin{array}{rr}0.004 \pm 0 & 0.01 \pm 0 \\ 0.004 \pm 0 & 0.004 \pm 0 \\ 0 & 0.004 \pm 0 \\ 0 & 0\end{array}$

$0.02 \pm 0 \quad 0.01 \pm 0.01$

$0.02 \pm 0 \quad 0.01 \pm 0.01$

$\begin{array}{rrr}0.1 \pm 0.01 & 0.04 \pm 0.01 & 0.1 \pm 0.04 \\ 0 & 0 & 0.01 \pm 0 \\ 0 & 0 & 0 \\ 0 & 0 & 0.004 \pm 0 \\ 0.04 \pm 0.01 & 0 & 0.03 \pm 0.03 \\ 0.004 \pm 0 & 0 & 0 \\ 0.1 \pm 0 & 0.03 \pm 0.02 & 0.1 \pm 0.01\end{array}$

Scarabaeidae

Total

Aphodius sp.

Aphodius lividus

Ataenius cribricollis

Athlia rustica

Lygirus villosus

Pleurophorus caesus

Staphylinidae

Total

Anothylus sp.

Apocellus opacus

Atheta inmucronata

Conosomus sp.

Gen. sp. 1

Gen. sp. 2

Gen. sp. 3

Homalotrichus sp.

Kainolimus sp.

Pagea vogelin

Philanthus hepaticus

Pseusolatra sp.

Gen. sp. 4

Gen. sp. 6

Gen. sp. 7

Gen. sp. 8

Gen. sp. 9

Gen. sp. 10

Gen. sp. 11

$\begin{array}{rrr}0.2 \pm 0.1 & 0.2 \pm 0.1 & 0.2 \pm 0.03 \\ 0 & 0 & 0 \\ 0 & 0 & 0 \\ 0,004 \pm 0 & 0 & 0 \\ 0 & 0 & 0.01 \pm 0 \\ 0 & 0 & 0.03 \pm 0.02 \\ 0.004 \pm 0 & 0 & 0 \\ 0 & 0 & 0 \\ 0.01 \pm 0 & 0 & 0 \\ 0 & 0 & 0 \\ 0.1 \pm 0.01 & 0.1 \pm 0.04 & 0.1 \pm 0.03 \\ 0.004 \pm 0 & 0.01 \pm 0 & 0.004 \pm 0 \\ 0.02 \pm 0 & 001 \pm 0.01 & 0.02 \pm 0 \\ 0 & 0 & 0.004 \pm 0 \\ 0 & 0.004 \pm 0 & 0 \\ 0 & 0.004 \pm 0 & 0 \\ 0 & 0.01 \pm 0 & 0 \\ 0 & 0.02 \pm 0.01 & 0 \\ 0 & 0 & 0 \\ 0 & 0.004 \pm 0 & 0 \\ 0 & 0.01 \pm 0.01 & 0\end{array}$

Gen. sp. 5
$0.01 \pm 0.01$
$0.03 \pm 0.01$

$0.03 \pm 0.01$
0

0
0
$0.004 \pm 0$

$0.1 \pm 0.1$

$0.1 \pm 0.04$

$0.4+0.1$

$0.04 \pm 0$

$0.3 \pm 0.1 \quad 0.03 \pm 0.01$

$0.004 \pm 0$

$0.004 \pm 0$

$0.1 \pm 0.03 \quad 0.004 \pm 0$

$0.3 \pm 0.01$

$0.01 \pm 0.01$

$0.4 \pm 0.1$

$0.5 \pm 0.04$

$0.01 \pm 0.01$

$0.1 \pm 0.01$

$0.3 \pm 0.03$

$0.1 \pm 0.1$

$0.3 \pm 0.03$

$0.3 \pm 0.03$
$0.2 \pm 0.1$

$0.4 \pm 0.1$

$0.02 \pm 0.01$

$0.3 \pm 0.1$

$0.1 \pm 0.03$

$\begin{array}{rrr}0.03 \pm 0.02 & 0.2 \pm 0.04 & 0.2 \pm 0.1 \\ 0 & 0.1 \pm 0.03 & 0.1 \pm 0.03 \\ 0.004 \pm 0 & 0.1 \pm 0.01 & 0.1 \pm 0.04 \\ 0.01 \pm 0 & 0 & 0 \\ 0.004 \pm 0 & 0 & 0.03 \pm 0.02 \\ 0.004 \pm 0 & 0 & 0.01 \pm 0.01 \\ 0 & 0.01 \pm 0 & 0 \\ 0 & 0.01 \pm 0 & 0.01 \pm 0 \\ 0 & 0.004 \pm 0 & 0\end{array}$

$$
\begin{aligned}
& 0 \\
& 0 \\
& 0 \\
& 0
\end{aligned}
$$

0

0
$0.2 \pm 0.04$
$0.1 \pm 0.01$
$0.004 \pm 0$
$0.004 \pm 0$
0
$0.01 \pm 0$
$0.004 \pm 0$
$0.1 \pm 0.04 \quad 0.03 \pm 0.01$

$0.02 \pm 0.01$

$0.004 \pm 0$

0
0

(0)

$$
0.1 \pm 0.03
$$

$0.3 \pm 0.04$ $0.004 \pm 0$

$0.3 \pm 0.04$

$0.004+0$

$$
\text { (0) }
$$

$0.03 \pm 0.03$
0

(1)

0
$0.004 \pm 0$

$0.05 \pm 0.03$

$0.004 \pm 0$

$0.01 \pm 0.01$

$0.02 \pm 0.02$

$$
0
$$

$$
\begin{array}{r}
0.004 \pm 0 \\
0
\end{array}
$$

0

$0.1 \pm 0.01 \quad 0.02 \pm 0.01$

$0.004 \pm 0$

$0.1 \pm 0.02$

$\begin{array}{rrr}0 & 0 & 0 \\ 0.04 \pm 0 & 0.02 \pm 0.01 & 0.01 \pm 0.01\end{array}$

$0.1 \pm 0.03$

$0.004+0$

0
0
$0.05 \pm 0$
0
0
0
0 
Beetle abundance per trap (mean \pm 1 SE)

Family/ species

Tenebrionidae

Total

Blapstinus punctulatus

Nycterinus toraxicus

Total abundance trap ${ }^{-1}$ Species trap ${ }^{-1}$

Species landscape ${ }^{-1}$
6 Dec 200220 Dec 2002 3 Jan 2003 17 Jan 2003 31 Jan 2003 18 Mar 20031 Apr 2003

$\begin{array}{rrrrrrr}0.5 \pm 0.2 & 0.1 \pm 0.02 & 0.1 \pm 0.04 & 0.1 \pm 0.03 & 0.2 \pm 0.1 & 0.03 \pm 0.02 & 0.02 \pm 0.01 \\ 1 \pm 0.2 & 0.1 \pm 0.03 & 0.1 \pm 0.04 & 0.1 \pm 0.02 & 0.2 \pm 0.01 & 0.03 \pm 0.02 & 0.02 \pm 0.01 \\ 0.01 \pm 0 & 0 & 0.004 \pm 0 & 0.01 \pm 0 & 0 & 0.004 \pm 0 & 0 \\ 3.0 \pm 0.1 & 3 \pm 0.4^{\mathrm{a}} & 4.1 \pm 0.4^{\mathrm{a}} & 5.0 \pm 1.2^{\mathrm{a}} & 11.2 \pm 5.0^{\mathrm{b}} & 4.1 \pm 0.1^{\mathrm{a}} & 3.4 \pm 0.2^{\mathrm{a}} \\ 1.8^{\mathrm{a}} & 1.9^{\mathrm{a}} & 2.2^{\mathrm{ab}} & 2.2^{\mathrm{ab}} & 2.5^{\mathrm{c}} & 2.5^{\mathrm{c}} & 2.1^{\mathrm{ab}} \\ 11.3^{\mathrm{a}} & 11.7^{\mathrm{ab}} & 14.1^{\mathrm{bc}} & 13.7^{\mathrm{ab}} & 14.2^{\mathrm{bc}} & 15.5^{\mathrm{c}} & 12.3^{\mathrm{ab}} \\ & & & & & & \end{array}$

